\title{
WHETHER FDI OR EXPORTS ENHANCE INNOVATION: EVIDENCE FROM INDIAN
} MANUFACTURING FIRMS, 2001-2012

Krishan SINGH ${ }^{1}$

Dr. Sandeep Kaur BHATIA2

${ }^{1}$ Research Scholar, Centre for Economic Studies, Central University of Punjab, Bathinda, India.

${ }^{2}$ Assistant Professor, Centre for Economic Studies, Central University of Punjab, Bathinda, India; kaursandeep00@gmail.com.

This paper was presented in 3rd Indialics conference , CDS, India, 2016.

\begin{abstract}
The economic reforms of 1991 resulted in an increased inflow of FDI into the Indian economy. However, for the invention of new techniques and skills, there is a great need to invest on $R \& D$, requires a huge amount of capital, which can be available through FDI inflows. Technology has been imported in heavy amount after the implementation of liberalization policies. Therefore, the present study intends to know whether FDI contributes to the Indian manufacturing sector through $R \& D$ or not. The average growth of the manufacturing sector in India (7.93 per cent) has been found considerably higher during the second decade of reforms (2001-2012) as compared to first decade reforms (1991-2000). In the context of this, the present study has tried to examine the trends and patterns of FDI and R\&D in manufacturing firms of India during the second decade of reforms (2001-12) and also, to analyze the impact of FDI and exports on R\&D in manufacturing firms of India through fixed effect model. The results suggest that R\&D has been significantly impacted by the import of capital goods, foreign equity, disembodied technology, and export intensity during the second decade of liberalization period. The present study suggests that greater approvals for foreign capital inflows are required in India, for enhancing the R\&D in the manufacturing sector. There must be an appropriate coordination between public and private sector, which can improve the $R \& D$ expenditure of manufacturing firms of India.
\end{abstract}

Keywords: FDI, Exports, R\&D, Manufacturing, liberalization, technology

\section{Introduction}

Foreign Direct Investment (FDI) is one of an important source of economic growth for economies where a gap between saving and investment exists. This saving investment gap is filled by FDI, which is a non-repayable external debt (Bohra, 2011). It brings new knowledge for the existing industries and new investors. Moreover, it helps to transfer of technology from developed countries to developing countries, which further enhances $R \& D$ expenditure in developing countries. It will also be helpful in enhancing the exports of the country and earning foreign exchange; it can be further used for necessary imports and other development projects. FDI in host country generates new techniques of production; it improves the productivity and efficiency of the domestic firms to maintain the quality of the product at low cost. It also plays an important role for manufacturing firms as it generates more production by using new, efficient and modern technology and increases employment opportunities (Joseph 2005), and also technological spillover improves the production of manufacturing firms and profitability with new sophisticated technology. The host country's firm can improve the efficiency of their production process with importing of new technology. There are many factors, which determine the FDI inflows any economy, such as economic stability, internal peace, market size, labor power, Government policies, natural resources, etc. (Singh, 2008). 
Research and Development (R\&D) is a necessary part of all developing economies because it improves the productivity of the firm during the production process. All multinational companies' incur expenditure on $R \& D$ through collaborative projects, joint venture, and amalgamations. R\&D expenditure improves the FDI inflows in the country. The market size is also an important, relevant, and attractive factor, especially for the R\&D intensive FDI, cost of labor is also an important, relevant driver, intellectual property right regime, climate and quality of life, English speaking skill of the local population, bureaucracy, paperwork, and stability are the functioning of R\&D intensive FDI (Guimon, 2008). The countries of the European Union have invested an average $1.89 \%$ of GDP on R\&D during 2000-2010. Sweden has invested an average amount of 3.65\% of whole GDP's on R\&D during 2000-10. Out of the whole world, this is the highest expenditure. Finland placed on the second number with 3.53\% of GDP; Japan invested 3.26\% of GDP and India has invested $0.75 \%$ of GDP on R\&D during 2000-12

Indian manufacturing sector has become an engine of growth, which provides nearly 100 million decent jobs. The Indian manufacturing sector attracts foreign capital in the form of FDI and Foreign Equity. With the liberal policies of 1991, the Indian government has approved up to 51 percent of FDI in high priority areas (Datt and Mahajan, 2013). Till 1991, there were many restrictions in India on the inflows of foreign capital. The Indian government has also given some relaxations for the import of new technology. At present almost 100\% FDI inflows are permitted in Petroleum Sector, Agriculture \& Husbandry, Tea Plantation, Mining, Coal \& Lignite, and Petroleum \& Natural Gas. Also, 100 percent FDI permitted in the manufacturing sector of India, but in Micro and Small Scale Enterprises (MSEs) of the manufacturing sector, 24 percent FDI has been permitted. In other manufacturing products related to defense government FDI is allowed only up to 26 percent (Rajalingam, 2011). Further 74 percent FDI has been permitted in the banking sector, 51 percent in the single retail sector and electronic \& electronic items. In Broadcasting sector also 74 per cent FDI has been permitted like in Direct to Home service (DTH) but 49 percent in cable networking (DIPP, 2012).

In October 2012, Indian manufacturing sector's growth was found the highest i.e. 9.8\%.In 2011 the expenditure on R\&D in the country was just only $0.9 \%$ of the GDP of India, out of which one-fourth is in the private sector and three fourth in the public sector (GOI, 2011). The flows of foreign R\&D in India are mainly concentrated in areas like electrical and communication, software development, auto design, etc. and near about 300 MNCs set their centers of R\&D. The Indian Government has also taken many steps for R\&D projects, especially where investments are high. The government provides many incentives for R\&D centers in India. In an Indian manufacturing sector, the government gives $200 \%$ deduction under section 35 (2AB) of Income Tax Act for both of capital and revenue expenditure for scientific $R \& D$, also tax credit instead of tax incentives like imposition of Minimum Alternative Tax (MAT) of 20\% through the company (Deloitte, 2011).

The growth of manufacturing sector is the present need of Indian Economy. For this, technology is an essential subject. However, for the invention of new techniques and skills, there is a great need to invest in $R \& D$, requires a huge amount of capital, which can be available through FDI inflows. India has a greater need to spend on $R \& D$ for the improvement of manufacturing sectors depth. Therefore, the present study attempts to know whether FDI is contributing to the manufacturing sector through R\&D. In this context, the study tries to give an answer to the question: whether FDI or exports 
stimulate innovation in Indian manufacturing sector. In this context, the paper is divided into five sections including the present one. The second section reviews the relevant literature on the current theme of the study. The third section explains the methodology used in the paper to examine the objectives. Section fourth explains the trends and patterns of selected Indian manufacturing firms for the period of 2001-2010 and explains the results through panel data regression analysis. Section fifth summaries results and discusses some policy implications.

\section{Review of Literature}

Expenditure on R\&D activities improves the production and productivity of a firm, increases the sales, profit and hence FDI inflows. There exists a big relation between FDI and R \&D. On these issues, there exists a vast literature. Mansfield (1962) attempted to analyze the role of innovation in the growth of firms. The study was based on the different time-period and analyzed data of steel, petroleum refining, rubber tire industries. The study observed that the small firms spend greater on R\&D, grow at a faster rate and their profits are high due to participation in innovations activities. The study suggested that increase of innovation activities is necessary for achieving greater benefits. Kumar(1987) analyzed the impact of FDI on R\&D for the period of 1976-77 to 1980-81 through 1720 non-governmental and non-financed public sector companies of India. Applying multiple regression, the study has found a negative impact of FDI on $R \& D$, but there were positive relations between the technology imports and local level of R\&D spending. The study suggested that the greatest improvement of FDI inflows has increased the R\&D expenditure, so favorable policies for FDI attraction are beneficial to the above-considered companies. Acs and Sasidharan and Kathuria(2008) examined the relation between FDI and $R \& D$ of 1,843 Indian manufacturing firms' for the period of 1994-2005. The study has taken FDI approvals data at the sectoral level and matched NIC with SIA classification as to obtain the total FDI approved in the each of 26 three-digit manufacturing sector industries. The study has been conducted to check the relation between FDI inflow and $R \& D$ behavior in manufacturing firms of India during the post liberalization period. The study explored that FDI induced only non-domestic firms for investment on R\&D. In the first stage, the analysis failed to clear the picture of the impact of FDI on domestic firm's innovation strategies, but later it has shown that technological efforts in the form of R\&D have decreased marginally in both domestic and foreign firms. The study suggests that domestic firms will invest on R\&D if a firm absorbs the technology spillover from foreign firms.

\section{Data and Methodology}

The present study is based on secondary data and relates to the time of 2001-12. Center for Monetary Indian Economy (CMIE) PROWESS is the major data source for the present study. There are nearly 5000 manufacturing firms in Bombay Stock Exchange (BSE), which has filtered on two steps as first exclude those firms, which have zero sales during any year of the study period and exclude all those firms, which have nil foreign equity in any year during the study period. Lastly, 315 Indian manufacturing firms of BSE belonged to 24 manufacturing industry groups of National Industrial Classification, 2008 have remained. The selected firms are mentioned in Appendix-I. Appropriate secondary data have also been collected from various sources such as RBI Annual Bulletin, Department of Industrial Policy and Promotion (DIPP), Economic Survey of India, World Bank, Annual Reports of Planning Commission, etc. 
To explain the relationship between FDI and $R \& D$, the study has selected the various variables from the literature, which is presented in Table 1. Kathuria (2000), SUN (2013), Ghosh \& Roy (2011), Parameswaran (2009), Behera et al (2012), Adamou \& S. (2008), Cheung \& Lin (2004) and Branstetter (2001) used various variables in their studies. The following econometric model is constructed and run through panel data methodology:

\section{$\mathrm{RDINT}_{\mathrm{i}, \mathrm{t}}=\beta_{0}+\beta_{1} \mathrm{AGE}_{\mathrm{i}, \mathrm{t}}+\beta_{2} \mathrm{DISTECH}_{\mathrm{i}, \mathrm{t}}+\beta_{3} \mathrm{EXPINT}_{\mathrm{i}, \mathrm{t}}+\beta_{4} \mathrm{FE}_{\mathrm{i}, \mathrm{t}}+\beta_{5} \mathrm{HHI}_{\mathrm{i}, \mathrm{t}}+\beta_{6} \mathrm{IMPCG}_{\mathrm{i}, \mathrm{t}}+\beta_{7} \mathrm{IMPRM}_{\mathrm{I}, \mathrm{t}}+$} $\beta_{8} \operatorname{size}_{i, t}+\mu_{i, t}$

$\mu_{\mathrm{i}, \mathrm{t}}=$ error term in ' $\mathrm{t}$ ' time period

The study has considered 315 cross sections and 12 years. To measure the impact of FDI on R\&D, the study used panel data methodology. Panel estimation can be done using pool estimation, fixed effect and random effect (Gujrati, 2003). All these three methods have been used to estimate the equation no. 1 and also to select the most efficient method for interpreting the estimation results, F-statistic test and Hausman test have been run.

Table 1. Description of Variables.

\begin{tabular}{|c|c|c|c|}
\hline \multicolumn{4}{|c|}{ Dependent Variable } \\
\hline 1. & \multicolumn{3}{|c|}{ R\&D as a proportion of annual sales } \\
\hline \multicolumn{4}{|c|}{ Independent variables } \\
\hline & Variable & Description & $\begin{array}{l}\text { Expected } \\
\text { sign }\end{array}$ \\
\hline 2. & $\operatorname{Size}\left(\mathrm{X}_{1}\right)$ & $\begin{array}{l}\text { Annual sale of firm as proportion of mean sales } \\
\text { of industry }\end{array}$ & + \\
\hline 3. & Foreign Equity $(\mathrm{FE})\left(\mathrm{X}_{2}\right)$ & Foreign promoter's share in total equity & + \\
\hline 4. & Export Intensity (EXPINT) $\left(\mathrm{X}_{3}\right)$ & Annual exports as proportion of annual sales & + \\
\hline 5. & $\begin{array}{l}\text { Capital goods import intensity } \\
\text { (IMPCG) }\left(\mathrm{X}_{4}\right)\end{array}$ & $\begin{array}{l}\text { Imports of machinery and equipments as } \\
\text { proportion of annual sales }\end{array}$ & + \\
\hline 6. & $\begin{array}{l}\text { Disembodied Technology } \\
\text { Imports Intensity (DISTECH) } \\
\text { (X5) }\end{array}$ & $\begin{array}{l}\text { Annual payment of royalties and technical fees } \\
\text { as proportion of annual sales }\end{array}$ & + \\
\hline 7. & $\begin{array}{l}\text { Raw material Import intensity } \\
\text { (IMPRM) }\left(\mathrm{X}_{6}\right)\end{array}$ & $\begin{array}{l}\text { Annual imports of raw material as proportion } \\
\text { of annual sales }\end{array}$ & + \\
\hline 8. & $\mathrm{HHI}\left(\mathrm{X}_{7}\right)$ & $\begin{array}{l}\text { Hirschman-Herfindahl index obtained as HHI= } \\
\text { (ith firm's annual sale / jth industry's annual } \\
\text { sale)^2 }\end{array}$ & + \\
\hline 9. & $\operatorname{AGE}\left(\mathrm{X}_{8}\right)$ & Calculated from incorporation year of the firm & + \\
\hline
\end{tabular}

Note: Words in the parenthesis are the short keys of variables. 


\subsection{Empirical Analysis}

\section{a)Trends and Patterns of FDI and R\&D in Indian Manufacturing Firms:}

Economic reforms of 1991 have enhanced the growth and performance of the Indian economy. The Second decade of economic reforms has been successful in attracting FDI inflows in India as industrial and service growth has contributed more to GDP during that time. Table 2 depicts the growth and performance of Gross Domestic Product (GDP), Inflows of Foreign Portfolio Investment (FPI) and Foreign Direct Investment (FDI) in India during 2001-12. GDP found as an increasing trend except 2008-09. The financial crisis affected GDP growth of Indian economy and pushed the economy in meager growth rate Impact of euro zone crisis has also seen on the Indian economy's GDP growth as 15.85 per cent deduction in 2011-12 as compared to 2010-11. On the other hand, Foreign Portfolio Investment (FPI), which consists of passive holdings of securities such as foreign stocks, bonds, or other assets, etc. have found decreasing trend during the whole period, except few years (2003-04, 2005-06, 2007-08, 2012-13). In 2003-04, the FPI inflows have shown as an $1102.97 \%$ increase as compared to last year. The greatest impact of US crisis has also found on flows of foreign portfolio investment, as $151.15 \%$ negative growth has been found in 2008-09. The picture of FDI inflows also shows fluctuating trend during the study period. The highest amount of FDI (US\$ 46553 million) has been originated in 2011-12 at 33.59 percent increase as compared to last year. The percentage share of FDI in GDP has also found the highest (3.42\%) in the same year. The 1.77\% annual average share of FDI in GDP has been found during 2001-12. The new economic and industrial policies of 1991 have given many incentives to attract foreign investment in India, and further Government of India extended the FDI limits across all sectors. Increasing share of India's trade in the world has also attracted a greater amount of FDI in the country (Sinha et al. 2007).

The picture of twenty-six sector's FDI inflows has been presented in Table 3 for 2000 2012. The service sector has received the highest amount of FDI inflows; it has captured nearly 27per cent share among the different sectors. Telecommunication has placed on second rank and Computer software, and hardware received 8.59 per cent of total inflows of FDI. The Pharmaceuticals industry groupi has attracted FDI of US\$ 9783.31 million in 2012; it has 7.23 percent share. The Automobile industry group has placed in the seventh position with 5.59 percent share. Approximately the same amount of FDI has attracted by the chemical industry group. The lowest FDI inflows have been received from timber products. Paper and Pulp, Air Transport, Agriculture Machinery and Earth Moving Machinery have absorbed less than 1 percent of total FDI. For study's considerable data, it has also found that the sectors containing large-sized firms have attracted a greater amount of FDI during the study period. But those firms belonging to small-scale industries have received a less amount of FDI, like Paper \& Pulp, Leather \& Related Products and Timber Products in the study period. Thus, Service Sector (26.94\%), Telecommunication (9.33\%), Agriculture Machinery $(0.15 \%)$, Earth Moving Machinery $(0.13 \%)$, Computer Software \& Hardware (8.59\%), Drug \& Pharmaceuticals (7.23\%) and Chemicals (6.47\%) are the top sectors which have received the greater FDI during the study period but the Air Transport (0.33\%), Leather, Leather Goods and Pickers (0.08\%) and Timber Products $(0.06 \%)$ have attracted the lowest amount of FDI inflows.

BSE's 315 manufacturing firms based on their foreign presence are divided into three groups on the basis of their sales in Table 4. The first group considers those firms, which have less than US\$ 10 million annual sales. These firms can attract a smaller amount of FDI due to lesser use of technology. Second and third groups are those firms having US\$ 10-50 million annual sales and greater than US $\$ 50$ million sales respectively. Contrary to 
the first group, it is hypothesized that the Hirschman-Herfindahl Index (HHI), a measure of market size and market concentration can be measured through the sale of a firm.

Table 2. Trends of GDP and FDI in India during 2001-2012. (US\$ million)

\begin{tabular}{|c|c|c|c|c|}
\hline Year & GDP & FPI Inflows & FDI Inflows & $\%$ age share of FDI in GDP \\
\hline $2000-01$ & 476609 & 2590 & 4029 & 0.85 \\
\hline 2001-02 & $\begin{array}{c}493954 \\
(3.64)\end{array}$ & $\begin{array}{c}1952 \\
(-24.63)\end{array}$ & $\begin{array}{c}6130 \\
(52.15)\end{array}$ & 1.24 \\
\hline $2002-03$ & $\begin{array}{c}523969 \\
(6.08)\end{array}$ & $\begin{array}{c}944 \\
(-51.64)\end{array}$ & $\begin{array}{c}5035 \\
(-17.86)\end{array}$ & 0.96 \\
\hline 2003-04 & $\begin{array}{l}618356 \\
(18.01)\end{array}$ & $\begin{array}{c}11356 \\
(1102.97)\end{array}$ & $\begin{array}{c}4322 \\
(-14.16)\end{array}$ & 0.7 \\
\hline 2004-05 & $\begin{array}{l}721586 \\
(16.69)\end{array}$ & $\begin{array}{c}9287 \\
(-18.22)\end{array}$ & $\begin{array}{l}6051 \\
(40)\end{array}$ & 0.84 \\
\hline 2005-06 & $\begin{array}{l}834215 \\
(15.61)\end{array}$ & $\begin{array}{c}12494 \\
(34.53)\end{array}$ & $\begin{array}{c}8961 \\
(48.09)\end{array}$ & 1.07 \\
\hline $2006-07$ & $\begin{array}{l}949117 \\
(13.77)\end{array}$ & $\begin{array}{c}7060 \\
(-43.49)\end{array}$ & $\begin{array}{c}22826 \\
(154.73)\end{array}$ & 2.4 \\
\hline 2007-08 & $\begin{array}{c}1238700 \\
(30.51)\end{array}$ & $\begin{array}{c}27433 \\
(288.57)\end{array}$ & $\begin{array}{c}34843 \\
(52.65)\end{array}$ & 2.81 \\
\hline 2008-09 & $\begin{array}{c}1224095 \\
(-1.18)\end{array}$ & $\begin{array}{c}-14031 \\
(-151.15)\end{array}$ & $\begin{array}{c}41873 \\
(20.18)\end{array}$ & 3.42 \\
\hline $2009-10$ & $\begin{array}{c}1365372 \\
(11.54)\end{array}$ & $\begin{array}{c}32396 \\
(130.89)\end{array}$ & $\begin{array}{l}37745 \\
(-9.86)\end{array}$ & 2.76 \\
\hline $2010-11$ & $\begin{array}{c}1710908 \\
(25.31)\end{array}$ & $\begin{array}{l}30293 \\
(-6.49)\end{array}$ & $\begin{array}{l}34847 \\
(-7.68)\end{array}$ & 2.04 \\
\hline $2011-12$ & $\begin{array}{c}1872840 \\
(9.46)\end{array}$ & $\begin{array}{c}17171 \\
(-43.32)\end{array}$ & $\begin{array}{r}46553 \\
(33.59)\end{array}$ & 2.49 \\
\hline $2012-13(\mathrm{P})$ & $\begin{array}{c}1841710 \\
(-1.66)\end{array}$ & $\begin{array}{c}26891 \\
(56.61)\end{array}$ & $\begin{array}{c}27197 \\
(-41.58)\end{array}$ & 1.48 \\
\hline
\end{tabular}

Source: SIA (FDI Data Cell), Department of Industrial Policy Promotion, Ministry of Commerce and Industry Dec. 2012, Reports of World Development Indicators. *P shows provisional estimates.

*Figures in the parenthesis shows percentage changes.

The first group of less than US\$ 10 million annual sales has shown its meager change in the average HHI during the whole study period. During 2003-06, it has found as 0.01 and marginally increased to 0.02 during 2007-12. Thus, it is clear that firms with less sales have a lower concentration. The second group has shown constant HHI value (0.02) during the whole study period except 2008. This may be due to the less capability and meager utilization of resources used by firms of these groups. The third group has shown HHI as 0.07 in 2001 and 2002, reduced to 0.06 in 2003 and 2004. An average HHI intensity, i.e. 0.05 has been found during 2005-12. With the increase in the sale of the firm, the foreign promoters share has also increased due to the re-investment of profit. R\&D intensity of different industry groups has shown dwindling trend during 2000-12. In the first group, the average R\&D was found at 0.07 in 2001, marginally increased and reached a level of 0.10 in 2012. The first group has contributed to an increasing trend of R\&D during 2001-12 but dwindling as compared to the second and third group. The second group has also found fluctuations in R\&D intensity till 2005, but after 2006 it increases at the marginal rate. The third group invests greater on $R \& D$ as compared to first and second. The R\&D intensity of the second group is less than the first and third group. The second group wishes to remain in the same position. But the firms of the third group demand progressive sales, so they prefer to expand greater on R\&D. The second group shows fluctuations in numbers of firms during the entire period. The 174 firms have reached their sales up to US\$ 50 million during the study period. 
Table 3. Sector-Wise FDI Inflows from April 2000 to December, 2012. (US\$ million)

\begin{tabular}{|l|l|c|c|}
\hline Sr. No. & \multicolumn{1}{|c|}{ Sector } & FDI Inflows & $\begin{array}{c}\text { Percentage } \\
\text { Share }\end{array}$ \\
\hline 1. & Service Sector (Financial and Non- financial) & 36449.49 & 26.94 \\
\hline 2. & Telecommunication & 12622.83 & 9.33 \\
\hline 3. & Computer Software \& Hardware & 11617.74 & 8.59 \\
\hline 4. & Drugs \& Pharmaceuticals & 9783.31 & 7.23 \\
\hline 5. & Chemicals(other than fertilizers) & 8758.81 & 6.47 \\
\hline 6. & Power & 7824.01 & 5.78 \\
\hline 7. & Automobile Industry & 7560.97 & 5.59 \\
\hline 8. & Metallurgical Industries & 7341.84 & 5.43 \\
\hline 9. & Petroleum \& Natural Gas & 5377.42 & 3.97 \\
\hline 10. & Electrical Equipments & 3092.37 & 2.29 \\
\hline 11. & Cement \& Gypsum Products & 2625.90 & 1.94 \\
\hline 12. & Mechanical \& Engineering Industries & 2287.89 & 1.69 \\
\hline 13. & Industrial Machinery & 2231.09 & 1.65 \\
\hline 14. & Construction (infrastructure) Activities & 1986.17 & 1.47 \\
\hline 15. & Food Processing Industries & 1681.97 & 1.24 \\
\hline 16. & Textiles(including Dyed, Printed) & 1220.02 & 0.90 \\
\hline 17. & Electronics & 1197.52 & 0.89 \\
\hline 18. & Rubber Goods & 984.72 & 0.73 \\
\hline 19. & Mining & 974.68 & 0.72 \\
\hline 20. & Paper and Pulp (Including Paper Products) & 861.88 & 0.64 \\
\hline 21. & Air Transport (including air freight) & 448.40 & 0.33 \\
\hline 22. & Agricultural Machinery & 208.53 & 0.15 \\
\hline 23. & Earth Moving Machinery & 171.37 & 0.13 \\
\hline 24. & Leather, Leather Goods, and Pickers & 103.27 & 0.08 \\
\hline 25. & Timber Products & 78.67 & 0.06 \\
\hline 26. & Miscellaneous Industry & 7801.38 & 5.77 \\
\hline Total & & 135292.25 & \\
\hline
\end{tabular}

Source: SIA (FDI Data Cell), Department of Industrial Policy Promotion, Ministry of Commerce and Industry.

Table 4. Classification of Firms on the Basis of Sales: Averages of HHI and RD

\begin{tabular}{|l|c|c|c|c|c|c|c|c|c|}
\hline & \multicolumn{3}{|c|}{ Sales: Less Than 10 } & \multicolumn{3}{c|}{ Sales: 10 to 50} & \multicolumn{3}{c|}{ Sales: Above 50 } \\
\hline & HHI & R\&D & $\begin{array}{c}\text { No. } \\
\text { of Firms }\end{array}$ & HHI & R\&D & $\begin{array}{c}\text { No. } \\
\text { of Firms }\end{array}$ & HHI & R\&D & $\begin{array}{c}\text { No. } \\
\text { of Firms }\end{array}$ \\
\hline 2001 & $\mathbf{0 . 0 1}$ & 0.07 & 100 & 0.02 & 0.02 & 118 & 0.07 & 0.12 & 97 \\
\hline 2002 & 0.02 & 0.02 & 105 & 0.02 & 0.01 & 117 & 0.07 & 0.04 & 93 \\
\hline 2003 & 0.01 & 0.02 & 88 & 0.02 & 0.01 & 118 & 0.06 & 0.37 & 109 \\
\hline 2004 & 0.01 & 0.02 & 84 & 0.02 & 0.01 & 117 & 0.06 & 0.54 & 114 \\
\hline 2005 & 0.01 & 0.05 & 73 & 0.02 & 0.04 & 113 & 0.05 & 0.79 & 129 \\
\hline 2006 & 0.01 & 0.08 & 69 & 0.02 & 0.04 & 111 & 0.05 & 1.35 & 135 \\
\hline 2007 & 0.02 & 0.16 & 64 & 0.02 & 0.05 & 100 & 0.05 & 1.40 & 151 \\
\hline 2008 & 0.02 & 0.26 & 62 & 0.03 & 0.07 & 78 & 0.05 & 1.95 & 175 \\
\hline 2009 & 0.02 & 0.24 & 67 & 0.02 & 0.08 & 89 & 0.05 & 2.07 & 159 \\
\hline 2010 & 0.02 & 0.34 & 56 & 0.02 & 0.11 & 92 & 0.05 & 2.48 & 167 \\
\hline 2011 & 0.02 & 0.52 & 54 & 0.02 & 0.17 & 88 & 0.05 & 2.90 & 173 \\
\hline 2012 & 0.02 & 0.10 & 52 & 0.02 & 0.43 & 89 & 0.05 & 2.90 & 174 \\
\hline
\end{tabular}

Source: Compiled from CMIE-PROWESS, 2013. Sales (US\$ million) 


\section{b) An Empirical Analysis of FDI, Exports and Technology Spillovers.}

The present statistical values have shown an existing interval of the relevant variables. The mean value of R\&D investments is found as 0.03 , and its standard deviation is 0.42 . Minimum and maximum values are found as 0 and 9.18 respectively. The 32.96 mean value and 19.85 standard deviation have been found for the age of the firm. Disembodied technology (DISTECH), an indicator of imported technology, has shown 0.0166 average values while its maximum and minimum value has been found as 7.925 and 0 respectively during 2001-12. Export Intensity (EXINT) of manufacturing firms of India has lied 0 to 174.71. HHI, an indicator of the firm's size and market concentration has been found as mean value of 0.16. Average of import of capital goods has found as 0.08 . Import of raw material has been contained by an interval group of 0 to 26.40.Size has found as an effective component of $R \& D$ expenditure lying between 0 and 2.32. The average value of size is measured as 0.08 during the study period.

Table 5. Summary Statistics of Variables Used for Analysis.

\begin{tabular}{|c|c|c|c|c|c|}
\hline Sr. No. & Variable & Mean & Std. Dev. & Min. & Max. \\
\hline 1. & R\&D Intensity (R\&D) & 0.0335 & 0.4177 & 0 & 9.18 \\
\hline 2. & Age (AGE) & 32.9635 & 19.8528 & 1 & 110 \\
\hline 3. & Disembodied Technology (DITECH) & 0.0166 & 0.1440 & 0 & 7.93 \\
\hline 4. & Export Intensity (EXINT) & 1.1473 & 7.4408 & 0 & 174.71 \\
\hline 5. & Foreign Equity (FE) & 37.9604 & 23.7435 & 0 & 96.8 \\
\hline 6. & Hirschman-Herfindahl Index (HH) & 0.1584 & 0.2909 & $0^{*}$ & 1 \\
\hline 7. & Import of Capital Goods (IMPCG) & 0.0764 & 0.4578 & 0 & 9.13 \\
\hline 8. & Import of Raw Material (IMPRM) & 0.1224 & 0.4980 & 0 & 26.40 \\
\hline 9. & Size (SIZE) & 0.0762 & 0.1915 & $0^{*}$ & 2.32 \\
\hline
\end{tabular}

Source: Calculated from PROWESS data. * shows nearly zero value.

The equation has been run through the above all mentioned methods. F-test is carried out to test the hypothesis that the firm-specific larger than the tabulated value supported that alternative hypothesis. Since the calculated F-statistics value (Restricted Ftest) is greater than the tabulated value therefore null hypothesis is rejected, and the alternative hypothesis is accepted. Hence, the firms have different propensities to spend on R\&D. Thus, it is clear that the pooled estimation gives biased results due to the omitted variables. Next, the Hausman Test is also performed to compare the fixed and random effect estimators. This statistical result has a value of 24.40 at eight d.f. which was also larger than the critical value. This suggests that the fixed effect is a better choice than the random effect. Therefore, the direction of the study focuses on the fixed effects estimation.

Estimated coefficients through different methods have nearly all expected signs except Hirschman-Herfindahl Index (HHI) and age of the firm. However, the magnitude of the coefficient has found nearly same, but the present study focuses on fixed effect model as suggested by restricted $\mathrm{F}$ test and Hausman test. According to the fixed effect model, the coefficient of the size has found positive but insignificant. The size of the firm has a positive impact on the R\&D intensity of firm indicating large sized firm invest more on $\mathrm{R} \& \mathrm{D}$. In other words, the positive relationship is due to the highest correlation between the size of the firm and R\&D expenditure. The insignificance of the variable is due to have a large no. of medium firms (those firms which have containing annual sale US\$ 10 million - US\$ 50 million) in the present data during 2001-12. According to Kathuria (2004) "The intensity of investment in R\&D is found to be greater in small size firms." The empirical literature shows similar results of this variable like Ghosh and Roy (2011), Kathuria 
(2004) and Karpaty and Lundberg (2002) but Kathuria (2000) shows this variable positive and insignificant. Next coefficient of import of capital goods (IMPCG) shows the significant and positive impact on the R\&D intensity of firms, indicating import of capital goods by firms encourages R\&D intensity.

Table 6: Impact of FDI, Exports on R\&D for Indian Manufacturing Firms (Using R\&D Intensity as dependent variable)

\begin{tabular}{|c|c|c|c|c|c|c|c|c|c|}
\hline \multirow[t]{2}{*}{ Variable } & \multicolumn{3}{|c|}{ Pooled OLS } & \multicolumn{3}{|c|}{ Fixed Effect } & \multicolumn{3}{|c|}{ Random Effect } \\
\hline & $\begin{array}{c}\text { Co- } \\
\text { efficient }\end{array}$ & $\begin{array}{c}\mathrm{t}- \\
\text { ratio }\end{array}$ & $\begin{array}{c}\mathrm{p}- \\
\text { value }\end{array}$ & $\begin{array}{c}\mathrm{Co}- \\
\text { efficient }\end{array}$ & $\begin{array}{c}\mathrm{t}- \\
\text { ratio }\end{array}$ & $\begin{array}{c}\mathrm{p}- \\
\text { value }\end{array}$ & $\begin{array}{c}\mathrm{Co}- \\
\text { efficient }\end{array}$ & $\begin{array}{c}\mathrm{t}- \\
\text { ratio }\end{array}$ & $\begin{array}{c}\mathrm{p}- \\
\text { value }\end{array}$ \\
\hline Size & 0.0200 & 0.72 & 0.471 & 0.0132 & 0.43 & 0.666 & 0.0181 & 0.64 & 0.519 \\
\hline IMPCG & $0.2536 * * *$ & 18.77 & 0.000 & $0.2485^{* * *}$ & 17.84 & 0.000 & $0.2524 * * *$ & 18.77 & 0.000 \\
\hline IMPRM & 0.0031 & 0.32 & 0.749 & 0.0032 & 0.33 & 0.749 & 0.0032 & 0.33 & 0.743 \\
\hline HHI & -0.0224 & -1.23 & 0.218 & 0.0058 & 0.30 & 0.766 & -0.0163 & -0.89 & 0.372 \\
\hline FE & $0.0003^{*}$ & 1.82 & 0.068 & $0.0003^{* * *}$ & 1.61 & 0.108 & $0.0003^{*}$ & 1.81 & 0.070 \\
\hline DISTECH & $\begin{array}{c}-0.415 \\
1 * * *\end{array}$ & 11.66 & 0.000 & $0.4147^{* * *}$ & 11.29 & 0.0000 & $0.4151 * * *$ & 11.72 & 0.000 \\
\hline EXPINT & $0.0287^{* * *}$ & 33.28 & 0.000 & $0.0287^{* * * *}$ & 32.07 & 0.000 & $0.0287^{* * *}$ & 33.42 & 0.000 \\
\hline Age & $0.0005^{*}$ & 1.96 & 0.050 & -0.0001 & -0.31 & 0.757 & 0.0004 & 1.46 & 0.143 \\
\hline $\mathrm{C}$ & -0.0365 & -3.39 & 0.000 & -0.0203 & -1.74 & 0.081 & -0.0332 & -2.97 & 0.003 \\
\hline $\begin{array}{l}\text { No.of } \\
\text { obs. }\end{array}$ & \multicolumn{3}{|c|}{3780} & \multicolumn{3}{|c|}{3780} & \multicolumn{3}{|c|}{3780} \\
\hline F-Stat & \multicolumn{3}{|c|}{444.6935} & \multicolumn{3}{|c|}{12.7996} & \multicolumn{3}{|c|}{444.6976} \\
\hline Prob. > F & \multicolumn{3}{|c|}{0.0000} & \multicolumn{3}{|c|}{0.0000} & \multicolumn{3}{|c|}{0.0000} \\
\hline R2 & \multicolumn{3}{|c|}{0.4854} & \multicolumn{3}{|c|}{0.5438} & \multicolumn{3}{|c|}{0.4854} \\
\hline $\begin{array}{c}\text { Hausman } \\
\text { Test }\end{array}$ & & & & & & & & .4039 & \\
\hline
\end{tabular}

* Significant at 10\% level, ** significant at $5 \%$ level and *** significant

According to Sasidharan and Kathuria (2008) "Once firms decide to spend on R\&D, the firms that opt for capital goods imports tend to have greater R\&D intensity." Parameswaran (2009), SUN (2013), and Sasidharan and Kathuria (2008) shows the similar results in their studies. Also, this may be due to the re-investment of profit. In addition, import of raw material (IMPRM) by firms has a positive and significant effect on their R\&D. Due to their increase in the intensity of imports of raw materials; their expenditure on R\&D has also increased.

Hirschman-Herfindahl Index (HHI), an indicator of market concentration, measured by sale share of the firm in the industry, shows the insignificant positive impact on the R\&D intensity in the present study, indicating that concentrated firms spend more on R\&D. The extent of their investment in $R \& D$ of these firms is not high therefore this variable found insignificant. The same results have found by Kathuria (2004), and Sasidharan and Kathuria (2008). Foreign Direct Investment is an important and essential component, which affects the R\&D expenditure of the firm. Foreign Equity (FE) is a type of FDI, its positive relation has been found with $R \& D$ through the studies of Sasidharan and Kathuria (2008), and Kathuria (2002). Highly significant and positive impact of this variable has been seen in our present data also. Disembodied technology has been measured through imports of Royalties techno-how and firms total sale. It revealed a highly significant and negative impact on R\&D at one per cent. According to Nursamsu and Hastiadi (2013), it is due to import of advanced technology. The increase in disembodied technology has compressed the expenditure of $R \& D$ during the study period. Import of technology can be divided into two parts i.e. embodied technology and disembodied technology. Embodied technology contains imports of the embodied products like new techniques and 
machinery, but disembodied technology includes expenditure on royalties, techno-how, etc. The intensity of expenditure on imports of disembodied technology is more than innovation expenditure (Joseph and Reddy 2009). Imports of technology are considered than expanding on $R \& D$. Due to this reason, firms have imported the required technology during the considerable time.

Total export goods divided by sales of firm constitute the export intensity which has shown a significant positive impact on R\&D. The present study indicates accumulated income from exports, improves the level of $R \& D$ expenditure. Kathuria (2000) and Kathuria (2004) have explained the insignificant positive impact of import of capital goods of Indian manufacturing firms, but SUN (2013) shows its significant negative impact on R\&D for Chinese manufacturing firms during the study period.

The results have also given a significant positive impact of age on R\&D at one percent level. The studies such as Sasidharan and Kathuria (2008), and SUN (2013) shows the similar results. The older firms expand greater on $R \& D$ as compared to new firms (Sasidharan and Kathuria 2008).

Thus, from the above analysis, it is clear that FDI shows a significant impact on $R \& D$ for Indian manufacturing firms. Other variables like import of capital goods, the size of the firm, HHI, the age of firm, export intensity, disembodied technology also have a significant impact on $R \& D$ during the second decade of reforms.

\section{Concluding Remarks}

The study has found that many of selected 315 Indian manufacturing firms belonging to 24-industry groups, cannot maintain foreign status. Only some industry like food products, paper and paper products, coke, refined products, fabricated metal products, machinery and equipments, and transport equipments and agriculture and fishing, mining and quarries, tobacco products and motor vehicles can maintain the foreign status. These industry groups spend $R \& D$ expenditure in sufficient amount and have a higher sales share as compared to remaining sectors. It means that more investment needs to be encouraged in other manufacturing sectors, which will further enhance $R \& D$ expenditure and balanced contribution from all sectors.

The present study has found that inflows of foreign capital have a positive and significant impact on R\&D expenditure. Therefore, greater approvals for foreign capital inflows are required in India. Sufficient expenditure on $R \& D$ is the need of an hour as India spends only 0.9 percent of GDP on R\&D in 2012, which is very much low as compared to other emerging economies. The public sector has done large amount expenditure on $R \& D$. An appropriate coordination has been required between public and private sector, which can improve the expenditure on $R \& D$.

Therefore, India is the global player in pharmaceuticals sector and it has by itself attracted 7.23 per cent FDI during 2000-2012. The three firms of this industry group, namely Ranbaxy Laboratory Ltd, Cipla Ltd. and Mylan Laboratories Ltd are toppers in expanding greater on R\&D during the study period. Therefore, to explore it's more potential, suitable policies regarding pharmaceutical innovation is required, which will make other firms to come forward. Import of capital goods and export intensity of the firm play a significant impact on $R \& D$. Therefore, the suitable government policies like reduction in tariffs are required to increase their trade. 


\section{Bibliography}

Acs, Z. J., and Audretsch, D. B. (1988) Innovation in Large and Small Firms: An Empirical Analysis." The American Economic Review 78(4),678-690. Retrieved December 9,2012, from http:/ / www.jstor.org/ stable/ 1811167?seq=1 \#page_scan_tab_contents.

Adamou, A., and S., Subash (2008) The Impact of R\&D and Foreign Direct Investment in Emerging Developing Countries: Evidence from Indian Manufacturing Industries. Working Paper- 37 Chennai, India. Retrieved December9,2012, from https:/ / ideas.repec.org/ p/ eab/ develo/ 22492.html.

Aggarwal, A.( 2000) Deregulation, Technology Imports and In-house R\&D efforts: An Analysis of the Indian Experience." Research Policy: 7,1081-1093.

Basant, R., and Fikkert, B. (1996) The Effects of R\&D, Foreign Technology Purchase and Domestic and International Spillovers on Productivity in Indian Firms. The Review of Economics and Statistics 78(2),187-199.

Basant, Rakesh (2011) Intellectual property protection, regulation and innovation in developing economies: the case of the Indian pharmaceutical industry." Innovation and Development 1(2): 115-133. doi:10.1080/ 2157930X.2011.551050

Battelle. (2013) India's Emerging competitiveness as destination of Global R\&D, Global R\&D Summit 2013 - Destination of India. FCCI Knowledge Paper. Retrieved May 7,2014,from http:/ / ficci.in/ spdocument/ 20284/ FICCI-Battelle-Knowledge-PaperGlobal-R\&D-Summit-2013\%5b1\%5d.pdf.

Behera, S. R., Dua, P., and Goldar, B. (2012) Foreign Direct Investment and Technology Spillover: Evidence Across Indian Manufacturing Industries." Delhi School of Economics, Delhi. Working Paper- 207. Retrieved F EBRUARY18,2013 ,from http:/ / www.cdedse.org/ pdf/ work207.pdf.

Bohra, A. S. (2011) Foreign Direct Investment in India Service Sector: A Study of Post Liberalization." IJER. MAR - APR : 10-18. Retrieved December 9,2012,from http:/ / www.ijeronline.com/ documents/ volumes/Vol2issue2/ ijer20110202(2).pdf

Branstetter, L. G. (2001) Are Knowledge Spillovers International or International in Scope? Micro econometric Evidence from the U.S. and Japan. Journal of International Economics 53: 53-79.

Chang, I., and Wall, H. (2005) Controlling for heterogeneity in Gravity Model of Trade Integration. Federal Reserve Bank of St. Louis Review 87(1): 49-63.

Cheung, K. Y., and Lin, P. (2004) Spillover Effects of FDI on Innovation in China: Evidence from the Provincial Data. China Economic Review 15 (1),25-44.

Chuang, Y. C., and Lin, C. M. (2007) Foreign Direct Investment, R\&D and Spillover Efficiency: Evidence from Taiwan's Manufacturing Firms. The Journal of Development Studies 35(4),117-137.

Cohen, W. M., and Levinthal, D. A. (1989) Innovation and Learning: the Two Faces of R\&D.The Economic Journal 99(397),569-596.

Datt, G., and Mahajan, A. (2013) Indian Economy.Chand \& Company Pvt. Ltd. New Delhi.

Dayar, E., and Pamuku, M. T. (2011) Analysis of Foreign Ownership, R\&D and Spillovers in Developing Countries: Evidence from Turkey. Economic Research Forum 5-27. Retrieved

December9,2012,from https:/ / scholar.google.co.in/ citations?view_op=view_citation\&hl=en\&user=uly2ARQ AAAAJ\&citation_for_view =uly2ARQAAAAJ:Y̌wf2qJgpHMC.

Deloitte. (2011) Research \& Development Expenditure: A Concept Paper.Retrieved July 7 , 2014 from www.deloitte.com/in. 
DIPP. (2012) Consolidated FDI Policy: Ministry of Commerce \& Industry. Government of India. New Delhi.

DIPP. (2012)FDI Data Retrieved June29, 2013,from www.dipp.nic.in: http:/ / dipp.nic.in/ English/ Publications/ FDI_Statistics/ 2012/ india_FDI_December2 012.pdf.

Economic Survey. (2007) Eleventh Five Year Plan. SAGE. India Pvt. Ltd. New Delhi. Retrieved December19,2012,from http:/ / indiabudget.nic.in/ es200708/ esmain.html.

Ghosh, M., and Roy, S. S. (2011) FDI, Firm Heterogeneity and Export: An Examination of Evidence in India. Bethune College, Kolkata India.

GOI. (2011) Faster, Sustainable and More Inclusive Growth: An Approach to the Twelfth Five Year Plan. Planning Commission. New Delhi. Retrieved December19,2012,fromhttp:/ / planningcommission.gov.in/ plans/ planrel/ 12appdrft / appraoch_12plan.pdf.

GOI. (2012) Economic Survey 2012-13. Ministry of Finance, Department of Economic Affairs. Oxford University Press. New Delhi. Retrieved June 29,2013,from http:/ / indiabudget.nic.in/ budget2013-2014/ survey.asp.

GOI. (2012) Twelfth Five Year Plan.SAGE. India Pvt. Ltd. New Delhi.

Guimon, J. (2008) Government Strategies to Attract R\&D- Intensive FDI. Journal of Development Economics: 137-142.

Gujrati, D. N. (2003) Basic Econometrics. McGraw-Hill. U.S. West Point 4: 604-712

Gupta, V., Gollakota, K., and Srinivasan, R. (2013) Business Policy and Strategic Management: Concept \& Applications.Journal of International Development 64,33-18.

Gustavsson, P., and Poldahl, A. (2003) Determinants of Firm R\&D: Evidence from Swedish Firm Level Data. FIEF. Working Paper- 190. Retrieved December9,2012,from http:/ / econpapers.repec.org/ paper/ hhsfiefwp/ 0190.htm

Hall, B. H., and Mairesse, J. (1995) Exploring the Relationship Between R\&D and Productivity in French Manufacturing Firms. NBER. Combridge. Working Paper 3956.

JCIG. (2013) White paper on Stimulation of Investment of Private sector into Research and Development in India. GOI. Ministry of Science and Technology. Department of Science and Technology. Retrieved December9,2012,from http:/ / dst.gov.in/ sites/ default/ files/ white-paper_0_0.pdf

Joseph, T.J. (2005), Foreign Ownership and Export Spillovers in Indian Manufacturing Industry under Liberalization, chapter 10 in the WORLD SUSTAINABLE DEVELOPMENT OUTLOOK 2005, Global Competitiveness: A Common Goal in a Digital Society, edited by Allam Ahmed and published by Emerald Group Publishing Limited, the U.K., 151-163.

Joseph, T., and Reddy, V. N. (2009) FDI Spillovers and export Performance of Indian Manufacturing Firms after Liberalization. Economic and Political Weekly 44(52), 97105.

Karpaty, P., and Lundberg, L. (2002) Foreign Direct Investment and Productivity Spillovers in Swedish Manufacturing. Orebro University and FIEF: 117-123.MORE DETAILS NEEDED.

Kathuria, V. (2000) Productivity Spillover from Technology Transfer to Indian Manufacturing Firms." Journal of International Development 12 (1):343-369. 
Kathuria, V. (2002) Liberalization, FDI, and Productivity Spillovers-An Analysis of Indian Manufacturing Firms. Oxford Economic Papers, 54,688-718.

Kathuria, V. (2008) The Impact of FDI Inflows on R\&D Investment by Medium and HighTech Firms in India in the Post-Reform Period. Transnational Corporation 17 (2),4666. http:/ / unctad.org/ en/ Docs/ diaeia20082a3_en.pdf

Kumar, N. (1987) Technology Imports and Local R\&D in Indian Manufacturing. The Developing Economies 25(3): 220-233.

Kumar, N. (2001) Determinants of Location of Overseas R\&D Activity of Multinational Enterprises: The Case of US and Japanese Corporations.Research Policy 159-174. doi:10.1016/ S0048-7333(99)00102-X.

Kumar, N., \& Pradhan, J. P. (2003) Export Performance of Indian Enterprises in Knowledge Based Industries: Recent Trends, Patterns and Implications." Discussion Papers- 42 RISDC, New Delhi. Retrieved December 19,2013,from http:/ / www.ris.org.in/ images/ RIS_images/ pdf/ dp42 pap.pdf.

Maira, A. (2013) Focus on Manufacturing Sector.The Hindu. Delhi. Retrieved December 29,2013,from http:// www.thehindu.com/ opinion/ op-ed/ focus-on-manufacturingsector/ article5072468.ece.

Mansfield, E. 1(962) Entry, Gibrat's Law and the Growth of Firm. The American Review 52(5): 1023-1151.

Monte, A. D., and Papagni, E. (2003) R\&D and the Growth of Firms: Empirical Analysis of a Panel of Italian Firms.Research Policy 32 (1),1003-1014.

Mrinalini, N., Nath, P., and Sandhya, G. (2013) Foreign Direct Investment in R\&D in India. Current Science 47(13),73-78.

Nursamsu, S., and Hastiadi, F. F. (2013) Analysis of International R\&D Spillover from International Trade and Foreign Direct Investment Channel: Evidence from Asian Newly industrialized Countries. Economics and Business. University of Indonesia. Working Paper No.- 3/13:10.

Parameswaran, M. (2009) International Trade, R\&D Spillovers and Productivity: Evidence from Indian Manufacturing Industry. The Journal of Development Studies 45(8),12491266.

Pradhan, J. P., and Abraham, V. (2005) Attracting Export-Oriented FDI: Can India Win the Race? Working Paper-156. Ahmadabad. Retrieved November 27,2012,fromhttp:/ / www.esocialsciences.org/ Download/ repecDownload.aspx?fna $\underline{\text { me=Document12022006240.128277.pdf\&fcategory=Articles\&AId=382\&fref }=\text { repec }}$

Pradhan, J. P., (2011) Regional heterogeneity and firms R\&D in India. Innovation and Development 1(2),259-282. doi:10.1080/ 2157930X.2011.614797.

Rahman, M. (2005) The Determinants of Bangladesh's Trade: Evidence from the Generalized Gravity Model.Working Paper ECON: 2005-3.

Rajalingam, P. (2011) Impact of Globalization on Indian Economy. Serials Publications: 23134.

Rasiah, Rajah, and Kumar, Ashish. (2008) Foreign Ownership, Technological Intensities and Economic Performance of Automotive Parts Firms in India. Asia Pacific Business Review 14(1), 85-102.

Sasidharan, S., and Kathuria, V. (2008) Foreign Direct Investment and R\&D: Substitutes or Complements - A Case of Manufacturing after 1991 Reforms. Working Paper- 4/ 08. United Nations Industrial Development Organisation (UNIDO). Vienna. 
Sasidharan, S., and Kathuria, V. (2011) Foreign Direct Investment and R\&D: Substitutes or Compliments - A Case of Indian Manufacturing after 1991 Reforms. Elsevier 39 (7),1226-1239. doi:10.1016/j.worlddev.2010.05.012.

Schneider, P. H. (2005) International Trade, Economic Growth and Intellectual Property Right: A Panel Data Study of Developed and Developing Countries.Journal of Development Economics 78 (1),529-547.

Singh, L. (2008) India's Economic Growth and Role of Foreign Direct Investment. Economic and Political Weekly 43(43),124-129.

Sinha, S. S., Kent, D. H., and Shomali, H. (2007) Comparative Analysis of FDI in China and India. Journal of Asia Entrepreneurship and Sustainability 3(2),102-13.

Sajid, A. and Sun, S. (2013) Foreign Entry and Firm R\&D. Journal of R\&D Management 43 (4),303-317.

Sajid, A. and Sun, S. (2013) Entry of foreign firms and the R\&D behavior: a panel data study of domestic and foreign firms in China's manufacturing sector. Econommics of Innovation and New Technology 23(8),739-757. doi: 10.1080/ 10438599.2014.887179.

SUN, S. (2013). Foreign Entry and Firm R\&D. 39th Australian Conference of Economists, 116.

Verbeek, M. (2004) A Guide to Modern Econometrics.Chichester: Wiley Pub.

Winter, S. G. (1984) Schumpeterian Competition in Alternative Technological Regimes. Journal of Economic Behavior and Organization 5,287-320.

World Bank. (2014). Data Retrieved December9,2012,from www.worldbank.org:http:/ / search.worldbank.org/ data?qterm=R\%26D\&language= EN\&op.

Yasuda, T. (2005) Firm Growth, Size, Age and Behavior in Japnese Manufacturing.Small Business $24 \quad$ (1), 1-15. Retrieved October 19,2013,from http:// www.jstor.org/ stable/ 40229405?seq=1 \#page scan tab contents.

Journal Revista Galega de Economia: http:/ / WWW.usc.es/ econo/ RGE/ benvidag.htm https:/ / ideas.repec.org/ s/ sdo/ regaec.html 